\title{
Antecedents of Intention to Leave the Organization: A Systematic Review
}

\author{
Andrea Valéria Steil ${ }^{1}$ (1) https://orcid.org/0000-0001-7853-6532 \\ Eduarda Vieira Floriani ${ }^{1}$ (1) https://orcid.org/0000-0002-5175-7404 \\ Janine da Silva Alves Bello ${ }^{1}$ (D) https://orcid.org/0000-0001-9290-5584
}

\begin{abstract}
The intention to leave the organization is a cognitive, deliberate and conscious process of a person quitting the organization he or she works in a near future. This study was designed to systematize the antecedents of the intention to leave the organization in empirical studies published in Portuguese between 2000-2015. We used a systematic review method to research 31 journals, proceedings of the Encontros da Associação Nacional de Pós-Graduação e Pesquisa em Administração (EnANPAD), ScIELO database, Google Scholar, and Theses and Dissertations Catalog - CAPES. Thirty-five publications were selected for analysis, where 18 antecedents were identified. Based on these results and on the theory of planned behavior, a model is proposed for understanding the relationships between the intention to leave, its antecedents, and the actual voluntary behavior of leaving organizations. The article indicates different paths to improve the understanding of behavioral variance related to the intention to leave the organization.
\end{abstract}

Keywords: intention, employee turnover, job rotation

\section{Antecedentes da Intenção de Sair da Organização: uma Revisão Sistemática}

Resumo: A intenção de sair da organização é um processo cognitivo, deliberado e consciente da pessoa deixar a organização na qual trabalha em um futuro próximo. Este estudo teve por objetivo sistematizar os antecedentes da intenção de sair da organização em pesquisas empíricas de língua portuguesa, publicadas entre 2000 e 2015. Utilizou-se o método de revisão sistemática de literatura para pesquisar 31 periódicos, anais dos Encontros da Associação Nacional de Pós-Graduação e Pesquisa em Administração (EnANPAD), SciELO, Google Acadêmico e Banco de Teses CAPES. Foram analisadas 35 publicações, nas quais foram identificados 18 antecedentes. A partir destes resultados e da teoria do comportamento planejado, propõe-se um modelo para a compreensão da relação entre a intenção de sair da organização, seus antecedentes e o comportamento de saída voluntária de organizações. O artigo indica diferentes caminhos para que se possa aumentar a explicação da variância do comportamento relacionado à intenção de sair da organização.

Palavras-chave: intenção, turnover, rotatividade de pessoal

\section{Los antecedentes de la Intención de Salir de la Organización: una Revisión Sistemática}

Resumen: La intención de salir de la organización donde trabaja es un proceso cognitivo, deliberado y consciente de uno para el futuro. Este estudio tuvo como objetivo sistematizar los antecedentes de la intención de salir de la organización en estudios empíricos en portugués, publicados entre 2000 y 2015. Se utilizó el método de revisión sistemática de literatura para investigar 31 periódicos, anales de los Encontros da Associação Nacional de Pós-Graduação e Pesquisa em Administração (EnANPAD), en las bases de datos SciELO, Google Académico y Banco de Tesis Capes. Se analizaron 35 publicaciones, en las cuales se identificaron 18 antecedentes. Desde los resultados y la teoría del comportamiento planeado, se propone un modelo para el entendimiento de la relación entre la intención de salir de la organización, sus antecedentes, y el comportamiento de salida voluntaria de las mismas. El estudio apunta diferentes caminos para que se pueda explicar más la varianza del comportamiento relacionado con la intención de salir de la organización.

Palabras clave: intención, turnover, rotación de personal

An intention refers to a person's decision to act and the effort he/she is willing to do in order to perform a behavior

${ }^{1}$ Universidade Federal de Santa Catarina, Florianópolis-SC, Brazil This research received a CNPq Research Grant. Call: MCTI/CNPQ/ Universal 14/2014. Process number: 446551/2014-7. This study was financed in part by the Coordenação de Aperfeiçoamento de Pessoal de Nível Superior - Brasil (CAPES) - Finance Code 001.

Correspondence Address: Andrea Valéria Steil. Universidade Federal de Santa Catarina. Centro de Filosofia e Ciências Humanas. Campus Reitor João David Ferreira Lima, s/n. Trindade, Florianópolis-SC, Brazil. CEP 88.040-900. E-mail: andreasteil@egc.ufsc.br
(Abraham \& Sheeran, 2003). By focusing its attention on intentions, the theory of planned behavior established parameters for understanding the cognitive antecedents of behavior (Ajzen, 1991): attitudes, subjective norms, and perceived behavioral control. The propositions of planned behavior theory state that people intend to engage in a behavior when they evaluate it positively (attitude), when they believe that people important to them want to see them engaged in this behavior (subjective norm), and when they perceive that the behavior is under their control (perceived behavioral control). 
Research with the theory of planned behavior has identified intention as the most important cognitive antecedent of behavior (Ajzen, 2011). Studies have shown that intentions account for between $20 \%$ and $30 \%$ of behavior variance in different domains (Armitage \& Conner, 2001; Sheeran, 2002). Examples include the relationship between intentions and health- related behaviors (Abraham \& Sheeran, 2003; Degen, Li, \& Angerer, 2015), choice of methods for selecting people (Langhammer, Bernhard-Oettel, \& Hellgren, 2012), exercising (Abraham \& Sheeran, 2003), staying or leaving an organization (Bobbio \& Manganelli, 2015; Glambek, Matthiesen, Hetland, \& Einarsen, 2014; Kim, 2015; Shukla \& Srivastava, 2016), among others.

The intention to leave the organization is a person's cognitive, deliberate and conscious process of leaving the organization voluntarily in the near future (Mowday, Porter, \& Steers, 1982). Research on the intention to leave the organization is largely based on Ajzen and Fishbein approaches related to intentions (Ajzen, 2011; Fishbein \& Ajzen, 1975). Mowday et al. (1982) proposed a model in which the intention to leave the organization is the last cognitive element before the person's final decision on leaving and actually leaving the organization.

If behavioral intent explains about $30 \%$ of behavioral variance (Armitage \& Conner, 2001), what other variables explain the specific behavior of voluntarily leaving an organization? An analysis of the antecedents of the intention to leave the organization in international studies points to a set of personal, occupational and environmental antecedents (Burakova, Ducourneau, Gana, \& Dany, 2014; Halawi, 2014; Treuren \& Frankish, 2014). Six personal antecedents have been researched more intensely: age, sex, schooling, marital status, family or kinship responsibility, and professional experience. Age-related studies indicate a negative relationship with the intention of leaving the organization: the older the age, the lower the intention to leave (Joseph, Ng, Koh, \& Ang, 2007). With regard to gender, men showed greater intention to leave than women (Ghapanchi \& Aurum, 2011). A consistent and positive relationship between schooling and intention to leave the organization was also verified. People with higher schooling showed greater intention to leave (Moynihan \& Landuyt, 2008).

In a relatively old study, married people were less likely to leave (Igbaria \& McCloskey, 1996). People with family, or kinship, responsibilities, married or not, also had less intention of leaving the organization in which they worked (Mobley, Griffeth, Hand, \& Meglino, 1979). Finally, professional experience presented negative relation with the intention to leave. The greater the professional experience, regardless of whether it was acquired in the current organization or not, the lesser the professional's intention to leave the organization in which he/she works (Mobley et al., 1979).

Two occupational antecedents to the intention to leave have been highlighted: job satisfaction and organizational commitment. Empirical evidence has shown a consistent and negative relationship between job satisfaction and intention to leave: the higher the satisfaction, the lower the intention to leave (Choi, Cheung, \& Pang, 2013; Nancarrow, Bradbury, Pit, \& Ariss, 2014). A strong negative relationship has also been found between organizational commitment and intention to leave (Mowday et al., 1982; Voigt \& Hirst, 2015).

International literature has also investigated the influence of environmental antecedents, which are stimuli and phenomena that exist in the environment external to the organization. Among these, the most researched are the positive macroeconomic factors and these include the heated labor market (Nancarrow et al., 2014), the existence of employment alternatives (Heinen et al., 2013; Lee \& Mitchell, 1994), the economic development level, employment policy, social security policy, labor supply and demand conditions ( $\mathrm{Li} \& \mathrm{Lu}, 2014$ ).

There is also evidence that work-family relationships are antecedents of the intention to leave (Lee \& Mitchell, 1994). Finally, sudden and unexpected events, called system shocks, have been associated with the intention to leave (Lee \& Mitchell, 1994). Examples include unsolicited job offers, changes in marital status, internal transfers, corporate mergers, etc., and, when incompatible with expectations, may arouse the intention to leave.

There are literature reviews on the history of turnover (Heavey, Holwerda, \& Hausknecht, 2013), but little is known about the intentions of leaving the organization in Portuguese language studies. The systematization of the antecedents of the intention to leave the organization in studies published in Portuguese is relevant for several reasons. The first is related to the advance in the understanding of the cognitive antecedents of the voluntary behavior of leaving the organization. The fact that the review focuses on empirical articles guarantees the systematization of variables already investigated and not merely hypothesized. The second is related to the shortage of qualified professionals in knowledge-intensive economic sectors in Brazil. These professionals have the essential knowledge, skills and attitudes for the organization to achieve its goals, are difficult to replace, and ask for dismissal more than are dismissed (Hofaidhllaoui \& Chhinzer, 2014). As organizations seek to retain these professionals (Guevara \& Bounfour, 2013; Steil, Penha, \& Bonilla, 2016), understanding what factors are related to the intention to leave the organization can help in this process. These contributions may be useful for directing future theoretical and empirical research on behavioral intentions related to the voluntary behavior of leaving organizations. This study, therefore, aimed to systematize the antecedents of the intention to leave the organization in empirical studies written in Portuguese and published between 2000 and 2015.

\section{Method}

This analysis followed the guidelines of the Preferred reporting items for systematic reviews and metaanalyses (PRISMA) with some adaptations, since these guidelines were outlined for systematic reviews and meta-analyses that evaluate randomized trials or health interventions. The authors of the PRISMA guidelines suggest that adaptations should be made to the guidelines when the focus of the review is different (Liberati et al., 2009). 
Of the 27 PRISMA guidelines, this review met 20, adapted four according to the aim of the review, and another three did not apply, as they are specific for meta-analyses. The sections of the guidelines followed were: title (guideline: title); abstract (guideline: structured abstract); introduction (guidelines: justification, aims); methods (guidelines: protocol and registry, eligibility criteria, sources of information, search, selection of studies, data collection process, data items, synthesis of results, additional analysis); results (guidelines: summary of evidence, limitations, conclusions), and research funding.

The four adapted guidelines are those related to the methods used to analyze potential bias in the studies and that may affect the accumulation of evidence about the randomized trials or intervention analyzed. This review was designed to identify antecedents of the intention to leave the organization, a construct that has been little researched in Brazil, and not the evaluation of randomized trials or analysis of any specific intervention. Accordingly, basic criteria were used to consider the items of methodological quality. The following were included: (1) publications identifying the sampling procedures, even if it was not probabilistic, (2) publications that presented information about the internal consistency of the measures used, and (3) surveys whose results were within the levels of significance $p<0.05$ or $p<0.01$.

From the use of these guidelines, the question that this review answers is: what are the antecedents of the intention to leave the organization identified in quantitative empirical studies published in Portuguese between 2000 and 2015? In order to avoid biases in the collection of publications, the search was broad and involved the following sources: 31 national journals of Psychology and Administration, publications of the Encontros da Associação Nacional de Pós-Graduação e Pesquisa em Administração, SciELO, Google Scholar, and Theses and Dissertations Catalog - CAPES.
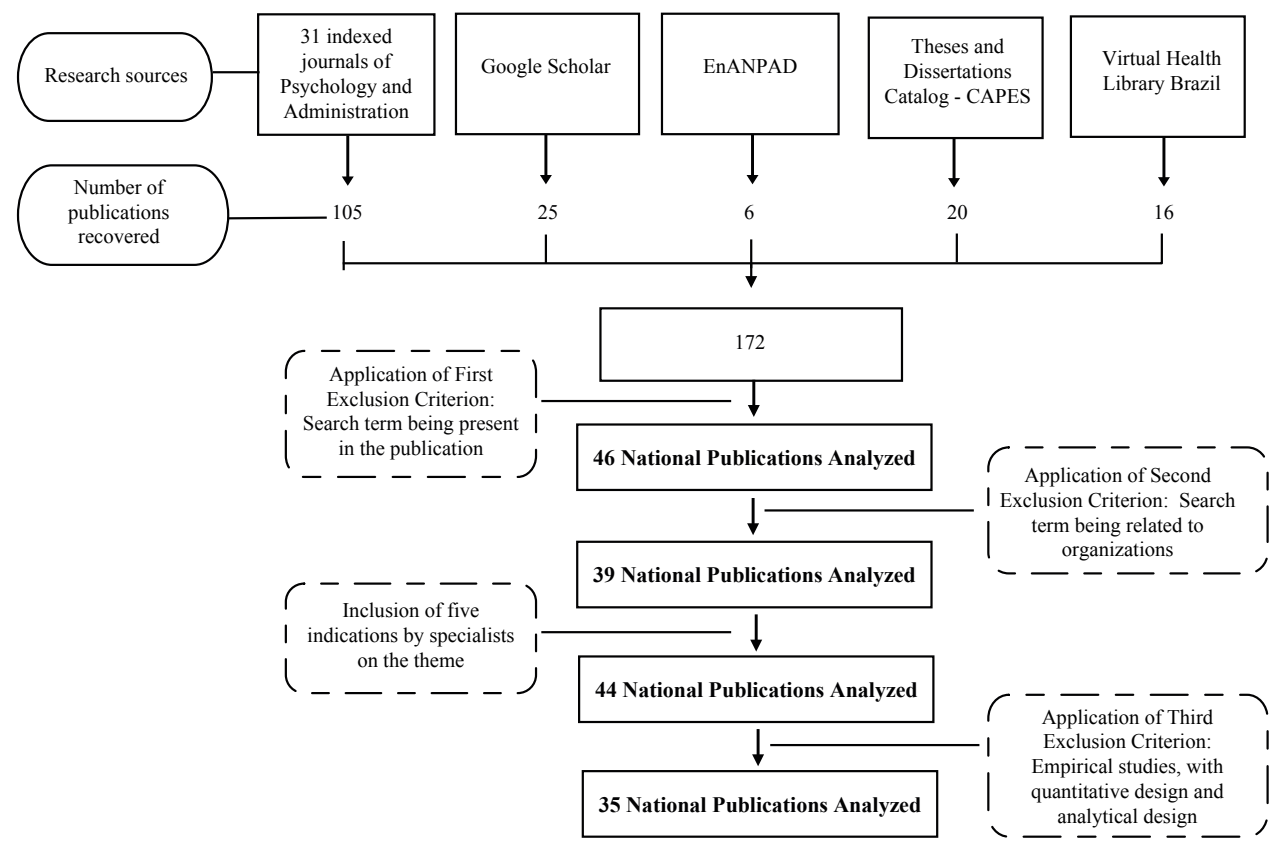

Figure 1. Strategies of search and selection of publications.
Two criteria were used for selecting journals: inclusion of all Psychology and Administration journals indexed to the SciELO database, and the use of 17 journals that traditionally publish articles on Organizational and Work Psychology in Brazil. With these criteria, 31 journals were selected for a systematic search. The search terms used in the journals were intenção de sair (intention to quit), intenção de deixar (intention to quit) and intenção de turnover (turnover intention).

Most searches in journals were done on title, abstract and keywords, except in cases where there were no such three search fields, in which case only keywords and title were used. In the Theses and Dissertations Catalog - CAPES, searches were done on the full text of theses and dissertations, and in Google Scholar, as it is a very comprehensive research source, the field "title" was used.

At the end of data collection, 172 publications were retrieved. Abstracts were read to apply the following inclusion criteria: the publication should describe an empirical study, with a quantitative design, and have intention to leave the organization as an analytical variable. To ensure these criteria, publications were analyzed in three rounds. In the first we checked if at least one search term was present in the publication. This criterion led to the exclusion of 126 publications and resulted in 46 publications for the second round. The second criterion was meant to ensure that the construct was organization-related. This led to the exclusion of seven publications, and a sample of 39 publications was thus obtained.

As recommended for systematic reviews, experts were contacted for indicating publications. In response to this request, five articles were included, totaling 44 publications for the sample. The latter filter selected publications with empirical studies with a quantitative design and intention to leave as a variable of analysis. With this refinement, nine publications were excluded. Figure 1 summarizes the search process and its results, with a total of 35 publications for the final sample. 
The review jury consisted of three people, who established the research question, defined journals and databases for data collection, as well as the inclusion and exclusion criteria. For data extraction, a form was created, where the following information was summarized: title, authors, method, instruments used, analytical strategy, sample, subjects, context, antecedents, antecedent measures, and direction of the relation with the intention to leave the organization.

After extracting the data, two judges categorized the antecedents into four a priori categories (personal antecedents, occupational antecedents, organizational antecedents and environmental antecedents). The third judge was called in cases where judges were unsure about which category the antecedent belonged to.

\section{Results and Discussion}

The majority of the 35 studies in Portuguese were carried out by Brazilian researchers (29 studies), with Brazilian samples. The others were conducted by Portuguese researchers.

We identified 18 antecedents of intention to leave the organization, with the following order of prevalence: satisfaction (13 studies), commitment (13 studies), perception of support (5 studies), work-family conflict (3 studies), quality of life at work (3 studies), well-being at work (3 studies), perception of career success (2 studies), organizational identification (2 studies), and perception of justice ( 2 studies). The other antecedents were identified in only one study: perception of gender inequality; positive psychological capital; employee trust in the organization; profile of organizational values; pleasure and suffering; perceived inconsistency between personal skills and demands on the individual's activities at work; counter growth, which refers to organizational limitations that prevent the development of the individual's abilities at work; perception of professional future in the organization; and perception of learning opportunities in the organization.

Table 1 presents the 18 antecedents categorized as occupational and organizational, with percentage of articles that investigated antecedents by category. The table also shows the direction of the relation of each antecedent with the intention to leave the organization and studies' authors. Occupational antecedents refer to factors related to the work performed or caused by the conditions of an occupation. Seventeen occupational antecedents were associated with the intention to leave the organization, and represent $95 \%$ of the antecedents researched. Organizational antecedents are those related to characteristics and practices of organizational level. Only one organizational antecedent was associated with the intention to leave the organization in one study.

Of the 18 antecedents described in Table 1, only five were positively associated with the intention to leave the organization: work-family conflict; perception of gender inequality; the "attrition" dimension of the pleasure and suffering construct; perceived incongruence between employee's skills and demands of his/her function in the organization; and perceived counter growth. All other antecedents presented negative relation with the intention to leave the organization.

The theory of planned behavior establishes that intentions determine behaviors and identifies three antecedents of intention: attitudes, subjective norms and perceived behavioral control. Of these, the international literature has researched two attitudinal antecedents: satisfaction and commitment. We did not identify international research with the antecedents subjective norms and perceived behavioral control.

Literature in Portuguese follows the pattern of international literature, with a focus on satisfaction and commitment as attitudinal antecedents to the intention to leave. Of the 35 studies in Portuguese, 21 investigated at least one of these antecedents. Like the results of international studies, no antecedent related to subjective norms or perceived behavioral control was investigated in the Portuguese language publications.

Satisfaction and commitment are attitudes because they involve cognitive judgments that can lead to behavioral responses (Judge \& Kammeyer-Mueller, 2012). Work satisfaction is an evaluative state that expresses contentment (cognitive aspect), as well as positive feelings (affective aspect) about work. On the other hand, commitment is an individual's psychological bond with the organization, represented by an affective connection with it, by internalization of its values and objectives, and by a desire to strive to support it (Judge \& Kammeyer-Mueller, 2012).

Although most of the studies analyzed investigated some attitudinal antecedent of the intention to leave, another 16 non-attitudinal antecedents were identified. It is questioned: what could be the relation of these other antecedents with planned behavior theory? It is proposed that this relationship can be established through attitudes. Judge and KammeyerMueller (2012) indicate that constructs measured by means of perception scales are, conceptually, antecedents of attitudes. This is the element that enables the development of a conceptual model for understanding the intention to leave from both the theory of planned behavior and the results of empirical research in Portuguese on the construct.

Figure 2 displays this conceptual model. It demonstrates the theory of planned behavior, focusing on the intention to leave as the behavioral intention of interest and voluntary leaving the organization as the consequent behavior. Satisfaction and commitment, attitudinal antecedents associated with the intention to leave, are placed in the attitudes cell. The model also shows twelve antecedents, measured with perception scales, as antecedents of attitudes (rather than as direct antecedents of the intention to leave the organization). This category includes: perception of support, perception of justice, perception of gender inequality, perception of career success, perception of learning opportunities in organizations, well-being at work (engagement dimension), positive psychological capital, organizational values profile, work-family conflict, incongruence between skill and demand, counter growth, and professional future. 
Table 1

Synthesis of antecedents to leave the organization, identified in empirical studies on the theme in Portuguese

\begin{tabular}{|c|c|c|c|}
\hline \multicolumn{2}{|c|}{$\begin{array}{l}\text { Occupational antecedents account for } 95 \% \text { of } \\
\text { antecedents }\end{array}$} & \multirow{2}{*}{$\begin{array}{l}\text { Direction of } \\
\text { relationship } \\
\text { Negative }\end{array}$} & \multirow{2}{*}{$\begin{array}{l}\text { Authors and country of study* } \\
\text { Cappi and Araujo (2015), Cavazotte, Oliveira, and Miranda (2009), } \\
\text { Dunzer (2012), Ferraz and Lopes (2015), Ferreira and Siqueira (2005), } \\
\text { Francisco and Claro (2015), Maciel and Camargo (2013), Mendes (2014), } \\
\text { Paranaíba (2014), Sacramento (2014), and K. L. A. B. Silva (2007) }\end{array}$} \\
\hline Satisfaction & At work & & \\
\hline & Professional & Negative & J. P. O. B. Oliveira (2009) \\
\hline & With organization's values & Negative & Garcia (2003) \\
\hline \multirow{6}{*}{ Commitment } & Affective & Negative & $\begin{array}{l}\text { Carmo (2009), Costa (2011), Costa and Bastos (2013), Ferreira } \\
\text { and Siqueira (2005), Francisco and Claro (2015), Garcia (2003), } \\
\text { Lima (2011), Luz, Paula and Oliveira (2015), Moreira (2009), H. V. } \\
\text { Oliveira (2015), and J. C. S. Silva (2011) }\end{array}$ \\
\hline & Continuation & Negative & Costa (2011) and Costa and Bastos (2013) \\
\hline & Calculative & Negative & Carmo (2009) \\
\hline & Instrumental & Negative & Dunzer (2012) \\
\hline & Normative & Negative & $\begin{array}{l}\text { Carmo (2009), Lima (2011), Luz et al. (2015), H. V. Oliveira (2015), } \\
\text { and J. C. S. Silva (2011) }\end{array}$ \\
\hline & Organizational & Negative & Cappi and Araujo (2015) \\
\hline \multirow[t]{2}{*}{ Perception of support } & Organizational & Negative & $\begin{array}{l}\text { Borges (2012), Carvalho (2012), Costa (2011), Costa and Bastos } \\
\text { (2013), and Diógenes (2012) }\end{array}$ \\
\hline & Social & Negative & Carvalho (2012) \\
\hline Work-family conflict & & Positive & $\begin{array}{l}\text { H. V. Oliveira (2015), L. B. Oliveira, Cavazotte, and Paciello (2013), } \\
\text { and Paciello (2012) }\end{array}$ \\
\hline Quality of work life & & Negative & J. P. O. B. Oliveira (2009), Rico (2010), and Torres (2010) \\
\hline Well-being at work & & Negative & $\begin{array}{l}\text { Agapito, Polizzi Filho, and Siqueira (2015), Polizzi Filho (2011), and } \\
\text { Polizzi Filho and Claro (2015) }\end{array}$ \\
\hline Organizational identifi & cation & Negative & Cavazotte et al. (2009), and Mendes (2014) \\
\hline \multirow{3}{*}{ Perception of justice } & Remuneration & Negative & Ferreira and Siqueira (2005) \\
\hline & Distributive & Negative & Lopes, Moretti, and Alejandro (2011) \\
\hline & Interpersonal & Negative & Lopes et al. (2011) \\
\hline \multicolumn{2}{|c|}{ Perception of gender inequality } & Positive & Cavazotte et al. (2009) \\
\hline \multicolumn{2}{|c|}{ Perception of successful career } & Negative & Agapito et al. (2015) and Dunzer (2012) \\
\hline \multicolumn{2}{|l|}{ Trust in the organization } & Negative & Carmo (2009) \\
\hline \multirow{2}{*}{ Pleasure and suffering } & Compensation & Negative & Pereira (2006) \\
\hline & Attrition & Positive & Pereira (2006) \\
\hline \multicolumn{2}{|c|}{ Perceived incongruence between skills and demands } & Positive & Maciel and Camargo (2013) \\
\hline \multicolumn{2}{|c|}{ Perceived counter growth } & Positive & Maciel and Camargo (2013) \\
\hline \multicolumn{2}{|l|}{ Professional future } & Negative & Vasconcellos and Neiva (2014) \\
\hline \multicolumn{2}{|c|}{ Perception of learning opportunities in organizations } & Negative & Freitas, Lacerda, Santos, and Alvarenga (2015) \\
\hline \multicolumn{2}{|c|}{ Positive psychological capital } & Negative & Polizzi Filho (2011) \\
\hline \multicolumn{2}{|c|}{ Profile of organizational values } & Negative & K. L. A. B. Silva (2007) \\
\hline
\end{tabular}

Note. ${ }^{*}$ Unless otherwise stated, the study was performed in Brazil.

In addition to antecedents measured with perception scales, the model comprises other four direct antecedents of the intention to leave the organization: organizational identification, trust in the organization, pleasure and suffering, and quality of life at work (measured through frequency scales). These antecedents are considered complementary to the theory of planned behavior, because they are not attitudes, they are not cognitive antecedents of attitudes, they are not subjective norms and they do not have established direct relation with the perceived behavioral control. These antecedents, added to the theory of planned behavior from empirical evidences of studies in the Portuguese language, are represented by the dashedline cells. 


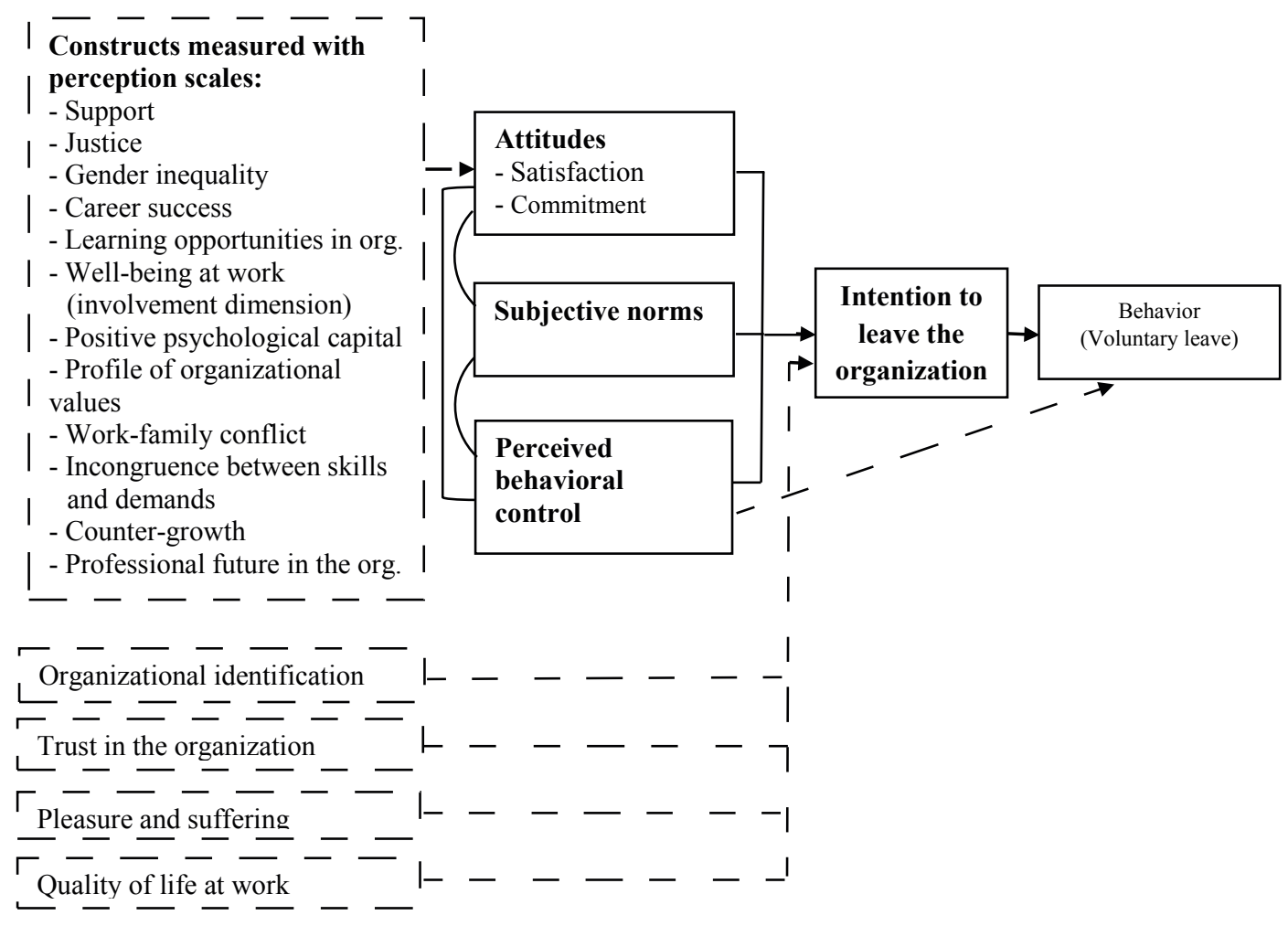

Figure 2. Model of analysis of the antecedents of the intention to leave the organization, built from the theory of planned behavior and empirical research on the construct.

The proposed model expands the theory of planned behavior to understand the intention to leave the organization. The model portrays satisfaction and commitment as the two main work-related attitudes that precede the formation of the intention to leave the organization. Based on the understanding of attitudinal formation, the model also proposes that the twelve variables measured with perception scales be considered antecedents of attitudes. Satisfaction and commitment would therefore be the mediators of these twelve variables' relation with the intention to leave the organization. Finally, the model proposes that the other four variables investigated in studies in Portuguese should be considered as direct antecedents of the intention to leave the organization.

This model is presented to the national scientific community to be submitted to empirical evaluation. Even with the systematization of the literature in Portuguese on the antecedents of the intention to leave the organization, presented in a model that adds these antecedents to the theory of planned behavior, this article has limitations. The model did not specify the strength of the relationship (high, moderate, weak) between antecedents and intention to leave the organization. The model also did not include individual variables (such as age, gender, schooling, marital status, kinship responsibility and professional experience), macroeconomic factors (e.g., economic situation of the country, labor market, employment alternatives) and system shocks. These variables have already been investigated in international research about intention to leave and may be relevant to the Brazilian context.

Finally, the decision to use basic criteria of methodological quality of the studies analyzed (information on the probabilistic sampling process, complete psychometric properties and pre-test of instruments, missing data, outliers, response rate and analytical technique used) has potential impacts on this study (Draugalis, Coons, \& Plaza, 2008). Some examples of these potential impacts include: the sample of 35 publications could have been smaller had stricter methodological criteria been used. In addition, the inclusion of publications with nonprobabilistic sample means that antecedents are valid for the samples surveyed (Fowler, 2014) and not for the population of workers in Brazilian and Portuguese organizations. Although this is an important limitation for a systematic review using the PRISMA guidelines, the decision to soften the criteria of methodological quality of publications to be analyzed was a conscious choice, given the aim of the review and the fact that it is a still an emerging topic in Brazil. We sought to expand the number of studies analyzed, so that an initial model could be developed, which should be tested empirically and rigorously by the national scientific community.

The aim of this study was to systematize antecedents of the intention to leave the organization in empirical studies in Portuguese, published between 2000 and 2015. The results and discussion allow to make some final considerations. 
The results of this review reinforce the importance of planned behavior theory, generating reflections on future research challenges for the area of cognitive antecedents to behaviors, and particularly for the antecedents of the intention to leave the organization. Different paths can be used to increase the explanation of behavior variance related to intention to leave the organization. The first is to deepen the knowledge about the antecedents of the intention to leave the organization with Brazilian samples. An equally promising path involves conducting longitudinal studies to understand the percentage of people intending to leave the organization who actually quit.

Vardaman, Taylor, Allen, Gondo, and Amis (2015) suggest the existence of contextual factors that explain why the reasons to leave the organization do not always lead to actual behavior. Contextual, environmental factors and system shocks could be tested as moderators of the relationship between the intention and behavior of leaving the organization. Ajzen (2002) had already pointed out that the transformation of intentions into behaviors is related to the employee's control of the decision. The employee evaluates how easy or difficult it would be for him/her to display the behavior, considering his/her personal resources against different factors, including environmental factors. Examples involve having another prospective job, having sufficient financial reserves to remain jobless for some time, or even the consent of his/her spouse to leave the organization without a work alternative (Ajzen, 2002).

These elements indicate the need to increase the understanding on the stability of the intention to leave the organization over time and the factors that influence its stability or change. As we advance in the understanding of behavioral intentions, we advance in increasing the capacity to explain work-related behaviors. We hope that this study will impel further research on the intentions to leave the organization and its relation with actually leaving (or staying in organizations).

\section{References}

Abraham, C., \& Sheeran, P. (2003). Acting on intentions: The role of anticipated regret. British Journal of Social Psychology, 42(Pt 4), 495-511. doi:10.1348/014466603322595248

Agapito, P. R., Polizzi Filho, A., \& Siqueira, M. M. M. (2015). Bem-estar no trabalho e percepção de sucesso na carreira como antecedentes de intenção de rotatividade. RAM. Revista de Administração Mackenzie, 16(6), 71-93. doi:10.1590/1678-69712015/administracao.v16n6p71-93

Ajzen, I. (1991). The theory of planned behavior. Organizational Behavior and Human Decision Processes, 50(2), 179-211. doi:10.1016/0749-5978(91)90020-T

Ajzen, I. (2002). Residual effects of past on later behavior: Habituation and reasoned action perspectives. Personality and Social Psychology Review, 6(2), 107-122. doi:10.1207/S15327957PSPR0602_02
Ajzen, I. (2011). The theory of planned behaviour: Reactions and reflections. Psychology \& Health, 26(9), 1113-1127. doi:10.1080/08870446.2011.613995

Armitage, C. J., \& Conner, M. (2001). Efficacy of the theory of planned behaviour: A meta-analytic review. Britsh Journal of Social Psychology, 40(4), 471-499. doi:10.1348/014466601164939

Bobbio, A., \& Manganelli, A. M. (2015). Antecedents of hospital nurses' intention to leave the organization: A cross sectional survey. International Journal of Nursing Studies, 52(7), 1180-1192. doi:10.1016/j. ijnurstu.2015.03.009

Borges, E. A. (2012). Percepção do suporte organizacional $e$ intenção de rotatividade: Um estudo com servidores técnico-administrativos de uma instituição federal de ensino superior [Social support perception and turnover intention: A study with admistrative staff of a federal higher education institution] (Specialization dissertation). Retrieved from http://bdm.unb.br/ handle/10483/4192?mode $=$ full

Burakova, M., Ducourneau, J., Gana, K., \& Dany, L. (2014). Pronostic de l'intention de départ chez les sapeurs-pompiers volontaires en France [Predicting intention to leave among volunteer firefighters in France]. Psychologie Francaise, 59(4), 273300. doi:10.1016/j.psfr.2013.12.002

Cappi, M. N., \& Araujo, B. F. B. (2015). Satisfação no trabalho, comprometimento organizacional e intenção de sair: Um estudo entre as gerações X e Y. REAd. Revista Eletrônica de Administração (Porto Alegre), 21(3), 576600. doi:10.1590/1413-2311.0782014.54843

Carmo, G. (2009). Antecedentes da intenção de rotatividade: Comprometimento organizacional e confiança do empregado na organização [Antecedents of turnover intention: Organizational commitment and employee trust in the organization] (Master's thesis). Retrieved from http://www.pgpsi.ip.ufu.br/node/172

Carvalho, C. C. (2012). Suporte organizacional, suporte social e intenção de rotatividade [Organizational suppport, social support and turnover intention] (Undergraduate dissertation). Retrieved from http://bdm. unb.br/handle/10483/4245

Cavazotte, F. S. C. N., Oliveira, L. B., \& Miranda, L. C. (2009). Desigualdade de gênero no trabalho: Reflexos nas atitudes das mulheres e em sua intenção de deixar a empresa. Revista de Administração, 45(1), 70-83. doi:10.1016/s0080-2107(16)30510-6

Choi, S. P., Cheung, K., \& Pang, S. M. (2013). Attributes of nursing work environment as predictors of registered nurses' job satisfaction and intention to leave. Journal of Nursing Management, 21(3), 429-440. doi:10.1111/ j.1365-2834.2012.01415.x 
Costa, F. M. (2011). Dinâmica do comportamento organizacional: Um estudo longitudinal entre trabalhadores de organizações agrícolas [Dinamics of organizational behavior: A longitudinal study with workers of agricultural organizations] (Doctoral dissertation). Retrieved from https://pospsi.ufba.br/sites/ pospsi.ufba.br/files/fabiola_marinho_tese.pdf

Costa, F. M., \& Bastos, A. V. B. (2013). Transformações em organizações de fruticultura irrigada e a dinâmica do comprometimento organizacional. REAd. Revista Eletrônica de Administração (Porto Alegre), 19(3), 675708. doi:10.1590/S1413-23112013000300006

Degen, C., Li, J., \& Angerer, P. (2015). Physicians' intention to leave direct patient care: An integrative review. Human Resources for Health, 13, 7486. doi:10.1186/s12960-016-0166-z

Diógenes, L. C. (2012). Intenção de rotatividade $e$ percepção de suporte organizacional em um órgão público federal [Turnover intention and perception or organizational support in a public sector organization] (Specialization dissertation). Retrieved from http://bdm.unb.br/bitstream/10483/4265/1/2012_ LarissaCoutinhoDiogenes.pdf

Draugalis, J. R., Coons, S. J., \& Plaza, C. M. (2008). Best practices for survey research reports: A synopsis for authors and reviewers. American Journal of Pharmaceutical Education, 72(1), 11. doi:10.5688/ aj720111

Dunzer, R. A. (2012). Os impactos das práticas de gestão de carreiras nas atitudes de trabalhadores de uma grande empresa brasileira [Impacts of career practices management on employees' attitudes of a large brazilian organization] (Master's thesis). Retrieved from http:// s3.amazonaws.com/public-cdn.ibmec.br/portalibmeccontent/public/arquivos/df/dis_2012_44_-_rodrigo_ alan_dunzer.pdf

Ferraz, R., \& Lopes, E. (2015). Satisfação no trabalho: Comparação de duas escalas de medida por meio de equações estruturais. Revista de Gestão dos Países de Língua Portuguesa, 14(1), 37-47. Retrieved from http://www.scielo.mec.pt/scielo.php? script $=$ sci $_{-}$ arttext\&pid=S1645-44642015000100005

Ferreira, M. L. C. B., \& Siqueira, M. M. M. (2005). Antecedentes de intenção de rotatividade: Estudo de um modelo psicossocial. Organizações em Contexto, 1(2), 47-67. doi:10.15603/1982-8756/roc.v1n2p\%2047\%20 $-\% 2067$

Fishbein, M., \& Ajzen, I. (1975). Belief, attitude, intention and behavior: An introduction to theory and research. Reading, MA: Addison-Wesley.

Fowler, F. J., Jr. (2014). Survey research methods (5th ed.). Los Angeles, CA: Sage.
Francisco, J. D. S., \& Claro, J. A. C. S. (2015). O impacto de satisfação no trabalho e de comprometimento organizacional afetivo sobre intenção de rotatividade em empresa mineradora de diamante (Angola). Revista Brasileira de Administração Científica, 5(3), 114-136. doi:10.6008/SPC2179-684X.2014.003.0007

Freitas, A. D. G. F., Lacerda, F. M., Santos, E. A., \& Alvarenga, M. A. (2015, setembro). Intenção de rotatividade: Um enfoque a partir das políticas de recursos humanos e da percepção de oportunidades de aprendizagem nas organizações. Anais do Encontro Nacional da Associação Nacional de Pós-Graduação e Pesquisa em Administração, 39, 1-17. Retrieved from https://www.researchgate.net/publication/281927130_ Intencao_de_Rotatividade_Um_Enfoque_a_Partir_das Politicas_de_Recursos_Humanos_e_da_Percepcao_de_ Oportunidades_de_Aprendizagem_nas_Organizacoes

Garcia, L. D. F. (2003). Análise de um modelo preditivo para a intenção de sair da organização [Analysis of a predictive model to intention to leave the organization] (Master's thesis). Retrieved from http://tede2.pucgoias. edu.br:8080/handle/tede/1928

Ghapanchi, A. H., \& Aurum, A. (2011). Antecedents to IT personnel's intentions to leave: A systematic literature review. Journal of Systems and Software, 84(2), 238-249. doi:10.1016/j.jss.2010.09.022

Glambek, M., Matthiesen, S. B., Hetland, J., \& Einarsen, S. (2014). Workplace bullying as an antecedent to job insecurity and intention to leave: A 6-month prospective study. Human Resource Management Journal, 24(3), 255-268. doi:10.1111/1748-8583.12035

Guevara, D., \& Bounfour, A. (2013). Monitoring intellectual capital: A case study of a large company during the recent economic crisis. Knowledge Management Research \& Practice, 11(2), 196-207. doi:10.1057/kmrp.2013.12

Halawi, A. H. (2014). Stimuli and effect of the intention to leave the organization. European Scientific Journal, 1, 184-198. doi:10.19044/esj.2014.v10n10p\%25p

Heavey, A. L., Holwerda, J. A., \& Hausknecht, J. P. (2013). Causes and consequences of collective turnover: A metaanalytic review. Journal of Applied Psychology, 98(3), 412-453. doi:10.1037/a0032380

Heinen, M. M., Achterberg, T. V., Schwendimann, R., Zander, B., Matthews, A., Kózka, M., Schoonhoven, L. (2013). Nurses' intention to leave their profession: A cross sectional observational study in 10 European countries. International Journal of Nursing Studies, 50(2), 174-184. doi:10.1016/j.jjnurstu.2012.09.019

Hofaidhllaoui, M., \& Chhinzer, N. (2014). The relationship between satisfaction and turnover intentions for knowledge workers. Engineering Management Journal, 26(2), 3-19. doi:10.1080/10429247.2014.11432006 
Igbaria, M., \& McCloskey, D. W. (1996). Career orientations of MIS employees in Taiwan. Computer Personnel, 17(2), 3-24. doi:10.1145/227728.227729

Joseph, D., Ng, K. Y., Koh, C., \& Ang, S. (2007). Turnover of information technology professionals: A narrative review, meta-analytic structural equation modeling, and model development. MIS Quarterly, 31(3), 547-577. doi: $10.2307 / 25148807$

Judge, T. A., \& Kammeyer-Mueller, J. D. (2012). Job attitudes. Annual Review of Psychology, 63, 341-367. doi:10.1146/annurev-psych-120710-100511

Kim, J. (2015). What increases public employees' turnover intention? Public Personnel Management, 44(4), 496519. doi: $10.1177 / 0091026015604447$

Langhammer, K., Bernhard-Oettel, C., \& Hellgren, J. (2012). Individual determinants of behavioral intentions: What tells us that practitioners really want to change hiring strategies? International Journal of Selection and Assessment, 20(4), 453-463. doi:10.1111/ijsa.12008

Lee, T. W., \& Mitchell, T. R. (1994). An alternative approach: The unfolding model of voluntary employee turnover. Academy of Management Review, 19(1), 51-89. doi:10.5465/amr.1994.9410122008

Li, P., \& Lu, H. (2014). Research on initiative turnover rate of the post-90s workforce - taking labor-intensive enterprises as an example. Journal of Human Resource and Sustainability Studies, 2(1), 12-25. doi:10.4236/jhrss.2014.21002

Liberati, A., Altman, D. G., Tetzlaff, J., Mulrow, C., Gotzsche, P. C., Ioannidis, J. P. A., Moher, D. (2009). The PRISMA statement for reporting systematic reviews and meta-analyses of studies that evaluate health care interventions: Explanation and elaboration. Annals of Internal Medicine, 151(4), W65-W94. doi:10.7326/00034819-151-4-200908180-00136

Lima, K. A. (2011). Intenção de rotatividade no serviço público e comprometimento organizacional: Um estudono Ministério da Integração Nacional [Turnover intention in the public sector and organizational commitment: A study in the Ministry of National Integration] (Master's thesis). Retrieved from http://bdm.unb.br/handle/10483/3536

Lopes, E. L., Moretti, S. L. A., \&Alejandro, T. B. (2011). Avaliação de justiça e intenção de turnover em equipes de vendas: Teste de um modelo teórico. Revista de Administração de Empresas, 51(6), 553-567. doi:10.1590/S0034-75902011000600005

Luz, C. M. D. R., Paula, S. L., \& Oliveira, L. M. B. (2015, novembro). Comprometimento organizacional e suas possíveis influências na intenção de rotatividade. Anais do Encontro de Gestão de Pessoas e Relações de Trabalho, 5, 1-18. Recuperado de https://www.researchgate. net/publication/319451010_Comprometimento_ Organizacional_e_suas_Possiveis_Influencias_na_ Intencao_de_Rotatividade
Maciel, C. O., \& Camargo, C. (2013). Sobrequalificação no trabalho e sua influência sobre atitudes e comportamentos. Revista de Administração Contemporânea, 17(2), 218238. doi:10.1590/S1415-65552013000200006

Mendes, A. M. V. (2014). Identificação organizacional, satisfação organizacional e intenção de turnover: Estudo com uma amostra do setor das telecomunicações [Organizational identification, organizational satisfaction and turnover intention: A study with a sample in the telecomunication sector] (Master's thesis). Retrieved from http://repositorio.ul.pt/bitstream/10451/18253/1/ ulfpie047256_tm.pdf

Mobley, W. H., Griffeth, R. W., Hand, H. H., \& Meglino, B. M. (1979). Review and conceptual analysis of the employee turnover process. Psychological Bulletin, 86(3), 493-522. doi:10.1037/0033-2909.86.3.493

Moreira, H. C. S. (2009). Qualidade de vida no trabalho, empenhamento organizacional afectivo e intenção de turnover: Que relações se estabelecem? [Quality of life at work, affective organizational commitment and turnover intention: What are the relations?] (Master's thesis). Retrieved from http://repositorio.ul.pt/ handle $/ 10451 / 2180$

Moynihan, D. P., \& Landuyt, N. (2008). Explaining turnover intention in State Government examining the roles of gender, life cycle, and loyalty. Review of Public Personnel Administration, 28(2), 120-143. doi:10.1177/0734371X08315771

Mowday, R. T., Porter, L. W., \& Steers, R. M. (1982). Employee-organization linkages: The psychology of commitment, absenteeism, and turnover. New York, NY: Academic Press.

Nancarrow, S., Bradbury, J., Pit, S. W., \& Ariss, S. (2014). Intention to stay and intention to leave: Are they two sides of the same coin? A cross-sectional structural equation modelling study among health and social care workers. Journal of Occupational Health, 56(4), 292300. doi:10.1539/joh.14-0027-OA

Oliveira, H. V. (2015). Conflito trabalho família e intenção de turnover nos bombeiros voluntários: A mediação pelo compromisso e diferenças de gênero [Work family conflict and turnover intention in voluntary firefighters: The mediating role of commitment and gender] (Master's thesis). Retrieved from http://repositorio.ul.pt/ handle/10451/20727

Oliveira, J. P. O. B. (2009). Relação entre intenção de turnover, qualidade de vida no trabalho e satisfação profissional: Estudo exploratório numa das melhores empresas para trabalhar em Portugal [Relations of turnover intention, quality of life at work and professional satisfaction: An exploratory study at one of the best organization to work in Portugal] (Master's thesis). Retrieved from http:// repositorio.ul.pt/handle/10451/2188 
Oliveira, L. B., Cavazotte, F. S. C. N., \& Paciello, R. R. (2013). Antecedentes e consequências dos conflitos entre trabalho e família. Revista de Administração Contemporânea, 17(4), 418-437. doi:10.1590/S1415-65552013000400003

Paciello, R. R. (2012). Impacto de politicas e práticas de redução do conflito trabalho-familia sobre resultados relacionados ao trabalho [Impact of politics and practices of reducing work family conflict on work related results] (Master's thesis). Retrieved from http://s3.amazonaws. com/public-cdn.ibmec.br/portalibmec-content/public/ arquivos/df/20473___raul_ricardo_paciello.pdf

Paranaíba, N. F. (2014). Satisfação no trabalho e intenção de rotatividade de servidores das carreiras de uma autarquia federal. In M. R. S. Camões, D. R. Fonseca, \& V. Porto (Orgs.), Estudos em gestão de pessoas no serviço público (pp. 117-142). Brasília, DF: ENAP.

Pereira, C. C. P. (2006). Relações entre configurações de poder, prazer e sofrimento e intenção de rotatividade: Estudo de caso numa empresa de tele-atendimento [Relations between power configurations, pleasure and suffering, and turnover intention: Case study in a self service organization] (Master's thesis). Retrieved from http://www.pgpsi.ip.ufu.br/node/253

Polizzi Filho, A. (2011). O impacto de bem-estar no trabalho e de capital psicológico sobre intenção de rotatividade: Um estudo com professores [Impact of well being at work and psychologycal capital on turnover intention: A study with professors] (Master's thesis). Retrieved from http:// tede.metodista.br/jspui/handle/tede/13

Polizzi Filho, A., \& Claro, J.A. C. S. (2015). O impacto de bemestar no trabalho e de capital psicológico sobre intenção de rotatividade: Um estudo com professores universitários. Anais do Encontro Nacional da Associação Nacional de Pós-Graduação e Pesquisa em Administração, 39, 116.

Rico, J. R. M. V. (2010). Qualidade de vida no trabalho e intenção de turnover: Um estudo exploratório sobre influência das variáveis sexo e idade [Quality of life at work and turnover intention: An exploratory study on the influence of sex and age] (Master's thesis). Retrieved from http://repositorio.ul.pt/handle/10451/2636

Sacramento, F. C. (2014). Satisfação no trabalho e intenção de rotatividadenoserviçodecontroledetráfegoaéreodeBrasília [Work satisfaction and turnover intention at the Brasília air traffic service] (Undergraduate dissertation). Retrieved from http://bdm.unb.br/handle/10483/10646?mode=full

Sheeran, P. (2002). Intention-behavior relations: A conceptual and empirical review. European Review of Social Psychology, 12(1), 1-36. doi:10.1080/14792772143000003
Shukla, A., \& Srivastava, R. (2016). Meta analysis of the relationship between emotional intelligence and different behavioral intentions. Research Journal of Business Management, 10(4), 58-73. doi:10.3923/rjbm.2016.58.73

Silva, J. C. S. (2011). Comprometimento organizacional e intenção de rotatividade no metrô - DF [Organizational commitment and turnover intention at metro DF] (Undergraduate thesis). Retrieved from http://bdm.unb. br/handle/10483/2836

Silva, K. L.A. B. (2007). Impacto dos valores organizacionais e da satisfação no trabalho na intenção de rotatividade [Impact of organizational values and work satisfaction in turnover intention] (Master's thesis). Retrieved from http://www.pgpsi.ip.ufu.br/node/226

Steil, A. V., Penha, M. M., \& Bonilla, A. M. (2016). Antecedentes da retenção de pessoas em organizações: Uma revisão de literatura [Antecedents to people retention in organizations: A literature review]. Revista Psicologia: Organizações e Trabalho, 16(1), 88-102. doi:10.17652/rpot/2016.1.542

Torres, J. M. B. C. P. (2010). Qualidade de vida no trabalho (QVT) e intenção de turnover: Efeito preditor de dimensões de QVT na intenção de turnover [Quality of life at work (QLW) and turnover intention: Effect of prediction of QLW dimensions on turnover intention] (Master's thesis). Retrieved from http://repositorio.ul.pt/ handle $/ 10451 / 1904$ ?locale $=$ en

Treuren, G. J. M., \& Frankish, E. (2014). Pay dissatisfaction and intention to leave: The moderating role of personal care worker client embeddedness. Nonprofit Management and Leadership, 25(1), 5-21. doi:10.1002/nml.21108

Vardaman, J. M., Taylor, S. G., Allen, D. G., Gondo, M. B., \& Amis, J. M. (2015). Translating intentions to behavior: The interaction of network structure and behavioral intentions in understanding employee turnover. Organization Science, 26(4), 1177-1191. doi:10.1287/ orsc.2015.0982

Vasconcellos, V. C., \& Neiva, E. R. (2014). Avaliação de futuro profissional e sua relação com bem-estar no trabalho e intenção de desligamento. Gestão \& Planejamento, 15(2), 410-427. Retrieved from https://revistas.unifacs. br/index.php/rgb/article/viewFile/2737/2303

Voigt, E., \& Hirst, G. (2015). High and low performers' intention to leave: Examining the relationship with motivation and commitment. The International Journal of Human Resource Management, 26(5), 574-588. doi:1.1080/09585192.2014.922599 
Andrea Valéria Steil is a Professor of the Departament of Psychology of the Universidade Federal de Santa Catarina, Florianópolis-SC, Brazil.

Eduarda Vieira Floriani is a Master's Student of the Universidade Federal de Santa Catarina, Florianópolis-SC, Brazil.

Janine da Silva Alves Bello holds a Ph.D. from the Universidade Federal de Santa Catarina, Florianópolis-SC, Brazil.

\section{Authors' Contribution:}

All the authors made substantial contributions to the conception and design of this study, to data analysis and interpretation, and to revision and approval of the final version of the manuscript. All the authors assume public responsibility for the content of the manuscript.

Received: Jun. 06, 2017

1st Revision: Nov. 08, 2017

Approved: Nov. 28, 2017

How to cite this article:

Steil, A. V., Floriani, E. V., \& Bello, J. S. A. (2019). Antecedents of the intention to leave the organization: A systematic review. Paidéia (Ribeirão Preto), 29, e2910. doi:http://dx.doi.org/10.1590/1982-4327e2910 